\title{
ANONYMOUS CHAT SEBAGAI DAMPAK MARAKNYA CYBERBULLY
}

\author{
ANONYMOUS CHAT AS AN CYBERBULLY IMPACT
}

\author{
Annisa Nurul Fitri Holle \\ Wartawan Media Online aceshowbiz.com \\ Email : archangel24.ah@gmail.com
}

\begin{abstract}
Indonesian internet users reached 75,57 million and increased to 82 million which 50\% of them are teenagers aged 15-22 according to Markplus Insight in 2013 nevertheless Communications and Informatics Ministry in 2014. With high number of users, Akamai Technologies, Inc., reported on October 17, 2013 that cyberbully in Indonesia was the highest with 38\%. This provides two options: keep using internet with hard work surely, or leave online activity. Actually, according to Horney (1945), everyone basically has three basic needs. The first need is to approach others or the public to gain love or recognition. This can mean sharing the vent (the outpouring of the heart). The second need is to avoid the public to gain freedom and independence. Last, the need to oppose the public to gain power. However, considering the internet is something cannot be left if you want to remain a part of this rapidly growing world, communication through online and social network is obligatory. So, it is created a communication container for people who are vulnerable to cyberbully: anonymous chat. Apps without photo sharing, video or personal identity provider. Anonymous chat users who are dominated by vulnerable people to cyberbully, are also introverts unlikely to share personal identity in public through social media like Instagram or Facebook. These people feel safe from mass judgment and can speak their mind. This data was obtained after the author's interview with 20 Whisper users (one of anonymous chat apps).
\end{abstract}

Keywords: Cyberbully, anonymous chat, Whisper, freedom of speech

\begin{abstract}
ABSTRAK
Pengguna internet di Indonesia mencapai 75,57 juta orang dan telah mencapai 82 juta orang dimana hampir $50 \%$ penggunanya adalah remaja berusia 15 - 22 tahun menurut Markplus Insight tahun 2013 dan Kemenkominfo tahun 2014. Dengan pengguna internet yang tinggi, Akamai Technologies, Inc., melaporkan pada 17 Oktober 2013 cyberbully di Indonesia merupakan yang tertinggi dengan angka $38 \%$. Fakta ini meninggalkan dua pilihan: tetap menggunakan wadah online sebaikbaiknya -dengan kerja keras tentunya, atau meninggalkan aktivitas online sama sekali. Padahal, menurut Horney (1945), setiap orang itu pada dasarnya memiliki tiga kebutuhan dasar. Kebutuhan pertama adalah kebutuhan mendekati orang lain atau publik guna mendapatkan cinta atau pun pengakuan. Ini bisa berarti berbagi
\end{abstract}

ISSN 2338 - 0861 (cetak); e-ISSN 2621 - 8712 (online)

website : http://spektrum.stikosa-aws.ac.id 
curhat (curahan hati). Kebutuhan kedua adalah menjauhi publik guna mendapat kebebasan dan kemandirian. Terakhir adalah kebutuhan menentang publik guna mendapatkan kekuasaan atau kekuatan. Hanya saja, mengingat internet merupakan hal yang tak mungkin ditinggalkan jika ingin tetap menjadi bagian dari dunia yang berkembang pesat ini, berkomunikasi melalui online dan jejaring sosial merupakan keharusan. Maka, tercipta lah wadah komunikasi bagi orang-orang yang rentan terhadap cyberbully: anonymous chat. Aplikasi yang tidak menyediakan fitur berbagi foto, video atau pun identitas personal. Dominasi pengguna anonymous chat yang rentan terhadap cyberbully, merupakan orang-orang berkepribadian introvert yang tak senang membagi identitas personal di depan publik melalui media sosial seperti Instagram atau Facebook. Karena pengguna merasa aman dari penghakiman massa dan memiliki kemerdekaan menyuarakan isi kepala. Data ini didapatkan setelah wawancara penulis dengan 20 pengguna Whisper (salah satu aplikasi anonymous chat).

Kata kunci: cyberbully, anonymous chat, Whisper, kebebasan bersuara

\section{PENDAHULUAN}

Mereka yang pernah menonton film Disconnect garapan sutradara Henry Alex Rubin pasti akan sangat paham tentang betapa besar kekuatan internet yang dapat mengubah hidup seseorang dalam sekejap. Di film itu, ada tiga kisah sekaligus: pasangan suami istri yang kehilangan banyak uang lewat penipuan online, eksploitasi anak muda yang dijadikan alat fantasi seksual online, dan percobaan bunuh diri seorang remaja laki-laki karena frustasi akan pelecehan dan public humiliation yang dialaminya karena aktivitas online.

Kisah terakhir itu lah yang akan dibahas dalam karya ilmiah ini. Apa yang dialami anak itu sering disebut sebagai cyberbully atau yang jika dibahasa-Indonesiakan berarti intimidasi berbasis dunia maya.

Jurnal tentang cyerbully pada media sosial terdahulu yang ditulis oleh Muhammad Alam Akbar dan Prahastiwi Utari dari Program Studi Ilmu Komunikasi Fakultas Ilmu Sosial dan Ilmu Politik Universitas Sebelas Maret Surakarta menuturkan bahwa:

"Berdasarkan survey yang
dilakukan oleh Markplus Insight
(www.the-marketeers.com) per tahun
2013 dan data resmi Kemenkominfo
per tahun 2014, pengguna internet di
Indonesia mencapai 75,57 juta orang
dan telah mencapai 82 juta orang
dimana hampir 50\% penggunanya
adalah remaja berusia 15-22 tahun."

Dengan tingkat pengguna internet yang begitu tinggi, Akamai Technologies, Inc., sebuah perusahaan multinasional yang bermarkas di Cambridge, Massachusetts, Amerika Serikat merilis laporan mencengangkan pada 17 Oktober 2013. Akamai menyebutkan bahwa cyberbully di Indonesia merupakan angka tertinggi dengan 38\%, sangat berbeda dari Korea Selatan yang menduduki peringkat ke-10 dengan angka hanya $0,9 \%$.

Internet memang selalu menjadi pedang bermata dua. Jika seseorang bisa memanfaatkannya, dunia dapat 
dengan mudah berada di genggaman. Namun, jika seseorang sedikit saja salah menggunakan -atau tak memiliki keterampilan memadai untuk dapat mengoperasikannya, maka internet akan dengan mudah membunuh karakter dan identitas orang tersebut.

Hal ini telah dibuktikan dengan banyaknya kasus-kasus bunuh diri yang ternyata adalah korban cyberbully. Sebut saja salah satu remaja Amerika, Amanda Todd, yang mengalami cyberbully selama tiga tahun sampai akhirnya menggantung dirinya sendiri pada 10 Oktober 2012.

Fakta ini meninggalkan dua pilihan: tetap menggunakan wadah online sebaik-baiknya -dengan kerja keras tentunya, atau meninggalkan aktivitas online sama sekali. Hanya saja, mengingat internet merupakan hal yang tak mungkin ditinggalkan jika ingin tetap menjadi bagian dari dunia yang berkembang pesat ini, melakukan opsi kedua sepertinya hampir mustahil. Tingkat kemustahilan itu akan bertambah jika pengguna yang bersangkutan merupakan seorang kaum milenial di mana ia lahir dan tumbuh di tengah perkembangan teknologi dan komunikasi.

Bagi beberapa orang yang rentan terhadap cyberbully -entah mereka yang memang telah mengalaminya sendiri, atau mereka yang belum mengalami tapi sudah terlalu takut untuk menghadapi-ada kontradiksi antara ketakutan yang mereka rasakan dengan kebutuhan untuk terus aktif dan bersosialisasi di dunia maya.

Maka, dengan pesatnya perkembangan teknologi komunikasi, lahir lah berbagai aplikasi anonymous chat yang memfasilitasi orang-orang dengan kebutuhan semacam ini. Aplikasi-aplikasi ini, sebagaimana yang seringkali diklaim oleh penemunya, merupakan tempat menyalurkan ekspresi tanpa harus takut dihakimi atau dikenali.

Aplikasi ini tidak menyediakan fitur foto dan nama profil -walaupun di satu atau dua aplikasi disediakan fitur nama display yang biasanya nama pengguna telah disetel langsung oleh aplikasi untuk menjaga nama asli tetap aman. Tak ada jaringan pertemenan di sini. Seseorang bisa saja sedang berbicara dengan orang asing yang berjarak beratus-ratus kilometer jauhnya. Itu lah mengapa kebanyakan orang akan memakai Bahasa Inggris sebagai bahasa universal yang digunakan untuk berinteraksi dengan sesama pengguna.

Di sisi lain, meskipun aplikasiaplikasi ini dibuat dengan tujuan baik, tak dapat dipungkiri jika memang banyak yang menggunakan ini untuk hal-hal tabu. Beberapa orang menggunakannya untuk mengekspresikan fantasi seksual atau pun ajakan kencan semalam. Ada juga yang sengaja menyebar kebencian untuk individu atau kelompok tertentu.

Tapi, tentu tak adil jika hanya menyebutkan sisi buruk dari aplikasiaplikasi ini. Tak sedikit pula yang memang menggunakan anonymous chat sebagai tempat bercerita tanpa harus menghadapi publik. Ini membuat ketakutan mereka akan dihakimi atas apa yang mereka katakana jauh lebih berkurang. Sehingga, mereka bebas bertindak dan memiliki wadah untuk 
menyalurkan tekanan dari kehidupan di luar dunia maya yang keras.

Terbaginya dua macam pengguna pada aplikasi ini membuat quote Joker terasa familiar di antara pengguna aplikasi. Quote itu berbunyi:

"Give a man a mask, so he'll become his true self."

(Berikan seseorang sebuah topeng, maka ia akan menjadi dirinya sendiri)

Tak akan ada pencitraan dalam aplikasi ini karena itu toh tak akan berguna.

Satu hal yang menjadi keprihatinan adalah anak-anak muda yang menggunakan aplikasi ini umumnya memang memiliki kehidupan sulit. Tidak hanya di dunia nyata namun juga di dunia cyber di mana mereka merasa tidak aman mengekpos identitas personal. Maka, tak sulit untuk mengatakan jika cyberbully memang hal yang melatarbelakangi pengembangan aplikasi-aplikasi anonymous chat.

\section{METODE PENELITIAN (Cambria 12, ditebalkan)}

Menjelaskan langkah-langkah sistematis yang dilakukan dalam kegiatan penelitian. Yang dibahas dalam metode misalnya metodologi penelitian, subjek penelitian, pengembangan instrumen, teknik analisis data / uji statistik yang dilakukan. Metode penelitian menjelaskan tentang tahap penelitian secara rinci dan jelas sehingga dapat dirujuk oleh peneliti lain (repeatable and reproduceable).

\section{HASIL DAN PEMBAHASAN}

Cyberbullying adalah segala bentuk kekerasan yang dialami anak atau remaja dan dilakukan teman seusia mereka melalui dunia cyber atau internet. Cyberbullying merupakan kejadian seorang anak atau remaja diejek, dihina, diintimidasi, atau dipermalukan oleh anak atau remaja lain melalui media internet, teknologi digital atau telepon seluler (Choria Y, 2014).

Definisi ini menjelaskan jika korban atau pun tersangka cyberbully adalah anak-anak dan remaja, sehingga intimidasi yang diperuntukan oleh dan dari orang dewasa tidak dapat dikategorikan sebagai bully atau cyberbully.

Definisi cyberbully ini senada dengan yang dilontarkan oleh Kepala Divisi Riset dan Jaringan LBH Pers, Asep Komarudin, dalam berita Kompas di Jakarta pada Senin 26 September 2016 di mana ia menjelaskan bahwa menurutnya bullying merupakan istilah yang diperuntukkan untuk anak yang diintimidasi. Berita ini berisi tentang definisi korban yang tak Jelas, hingga menyebabkan aturan cyberbullying di revisi UU ITE dinilai tak tepat.

Dari dua definisi di atas, terkadang akan sedikit sulit membedakan bully dan cyberbully. Maka menenurut Kowalski dan Limber (2007), ada tiga hal yang membedakan tradisional bullying dengan cyberbullying. Pertama, tradisional bullying merupakan tindakan yang dilakukan secara langsung bertatap muka (face-toface), namun cyberbullying tidak. Pelaku menggunakan internet dan teknologi sebagai media, sehingga pelaku tidak harus bertemu muka dengan korbannya dan pelaku juga

ISSN 2338 - 0861 (cetak); e-ISSN 2621 - 8712 (online)

website : http://spektrum.stikosa-aws.ac.id 
tidak dapat melihat reaksi emosi korban. Kedua, dalam cyberbullying, pelaku tidak dapat menyerang secara fisik, namun lebih kepada psikis sang korban. Terakhir, tidak seperti tradisional bullying, cyberbullying dapat muncul kapan saja dan secara cepat dapat menyebarkan berita buruk mengenai korbannya dengan bantuan teknologi internet.

Namun, meski terdapat berbagai macam perbedaan, berdasarkan Choria Y dan Asep Komarudin, bully maupun cyberbully tetap lah ditujukan untuk anak-anak dan remaja. Tentu, perbedaan paling signifikannya hanya terletak pada media penyampaian intimidasi.

Cyberbully ini nantinya akan berdampak pada self-esteem personal yang rendah. Baumrind mendefinisikan self-esteem sebagai rasa penghargaan pada diri sendiri (1967). Sedangkan menurut Harter, self-esteem tumbuh dari dua akar yang mana salah satunya berasal dari penilaian orang lain. Seseorang yang memiliki kemampuan efektif dan mendapat respon positif dari orang lain akan memiliki self-esteem yang lebih tinggi (Harter dalam Baumeister, 1999).

Maka, seseorang yang mendapat cibiran terus-menerus akan memiliki persepsi yang rendah tentang dirinya sendiri. Ini menyebabkan ia takut untuk menyuarakan pendapat dan berekspresi dengan talenta yang dimilikinya.

Bullying UK National Survey 2014 melaporkan, 91\% dari orangorang yang mengalami cyberbullying mengaku bahwa mereka tidak mengambil tindakan apapun atas intimidasi tersebut.
Ini membuat kebanyakan remaja menanggung beban yang lebih berat karena menyimpan segala masalah sendirian. Padahal menurut Horney (1945), setiap orang itu pada dasarnya memiliki tiga kebutuhan dasar. Kebutuhan pertama adalah kebutuhan untuk mendekati orang lain atau publik guna mendapatkan cinta atau pun pengakuan. Ini bisa berarti berbagi kisah dengan orang lain. Kebutuhan kedua adalah kebutuhan untuk menjauhi publik guna mendapat kebebasan dan kemandirian. Dan yang terakhir adalah kebutuhan untuk menentang publik guna mendapatkan kekuasaan atau kekuatan.

Kebutuhan ini harus lah dipenuhi agar tak terjadi masalahmasalah psikis di kemudian hari. Masalahnya bagi anak-anak yang rentan akan cyberbully, mendapat kebutuhan pertama dari publik bukan lah hal yang mudah. Sebab, kita tahu jika dunia cyber adalah ruang terbuka di mana semua orang bebas memberikan pendapat terhadap suatu hal tertentu. Kebebasan berpendapat ini bisa berkembang menjadi penghakiman dan cibiran. Itu lah yang biasanya dihindari oleh anak-anak tersebut.

Bahkan, UU ITE tentang cyberbully hingga sekarang belum ada kejelasan. Bukan tanpa sebab, karena bisa saja peraturan itu dapat merenggut kebebasan berpendapat karena masih belum ada sekat yang pasti serta resmi antara bully dan kritik.

Maka, tugas perkembangan teknologi dan komunikasi lah yang memberi wadah bagi anak-anak yang rentan terhadap cyberbully untuk dapat bersuara dan mengungkapkan

ISSN 2338 - 0861 (cetak); e-ISSN 2621 - 8712 (online)

website : http://spektrum.stikosa-aws.ac.id 
keluh-kesahnya. Seperti yang telah dijelaskan sebelumnya bahwa teknologi pada akhirnya melahirkan beberapa aplikasi anonymous chat yang memungkinkan pengguna untuk berekspresi tanpa takut dihakimi.

Aplikasi ini juga berfungsi sebagai wadah mendapatkan teman bicara yang baru sehingga kebutuhan manusia untuk terus bersosialisasi dengan manusia lainnya dapat terpenuhi.

Adalah Whisper app yang merupakan salah satu anonymous chat paling tenar yang ada. Whisper dirilis pada 31 Maret 2012 dan merupakan aplikasi anonymous chat yang menyediakan fitur berbagi foto dan video (bukan koleksi pribadi) yang berisi tulisan-tulisan yang dibuat pengguna yang ingin mempublikasikannya pada sesama pengguna secara anonymous. Tulisan ini lah yang dinamakan whisper atau bisikan yang biasanya merupakan quote-quote karya mereka. Dari quote ini, orang yang tertarik dapat melakukan privat message yang tentunya juga dilakukan secara anonymous.

Memakai Whisper akan sama rasanya seperti memakai media sosial lainnya yang dapat mengirimkan status -whisper di app ini dapat dikategorikan sebagai status-dan mendapat respon dari orang lain. Bedanya, di Whisper semua orang "tak berwajah" dan bebas dari penghakiman.

Respon yang dapat diberikan di Whisper berupa like berbentuk hati dan fitur membalas menggunakan whisper -yang berarti tidak ada fitur komentar di sini kecuali saling membalas quote. Jika tak ingin membalas whisper di muka umum namun ingin menananggapi, fitur yang disediakan adalah privat message.

Dengan begitu, Sang CEO, Michael Heyward, selalu mengatakan jika Whisper akan menjadi wadah yang menampung segala aspirasi publik tanpa mereka harus ketakutan akan akibat yang nantinya timbul.

\section{Perkembangannya}

Seperti teknologi-teknologi lainnya, anonymous chat dapat dianalisis melalui teori difusiinovasi dari Everett Rogers (1995).

Inovasi, seperti yang telah umum diketahui, merupakan suatu ide yang dianggap sebagai hal yang baru oleh suatu kelopok masyarakat. Inovasi dapat berupa hal yang memang benar-benar baru tercipta, atau juga dapat berupa suatu perkembangan dari hal yang sudah ada dan umum di masyarakat.

Inovasi ini kemudian disebarkan kepada masyarakat luas melalui berbagai media sehingga nantinya dapat mengubag sistem sosial masyarakat. Difusi ini merupakan suatu hal yang tak terelakkan karena perkembangan teknologi menuntut manusia untuk menyesuaikan diri.

Itu lah mengapa anonymous chat dan difusi-inovasi merupakan hal yang tak dapat dipisahkan. Nanti di suatu masa, bukan tidak mungkin aplikasiaplikasi anonymous chat ini menjadi sangat popular sampai dapat mengalahkan raksasa media online seperti Facebook, Twitter atau Instagram. Semua karena

ISSN 2338 - 0861 (cetak); e-ISSN 2621 - 8712 (online)

website : http://spektrum.stikosa-aws.ac.id 
sistem sosial masyarakat telah bergeser dan menganggap bahwa mengekspos identitas personal ke publik merupakan sesuatu yang tabu.

Namun, sebelum difusi atas anonymous chat besar-besaran terjadi, tentu kita sebagai tokoh utaa dalam semua perubahan ini harus melewati beberapa proses keputusan inovasi (The Innovation-Decision Process). Menurut Everett Rogers ada lima tahap dalam keputusan inovasi. Tahapan-tahapan itu adalah knowledge, persuasion, decision, implementation dan confirmation.

\section{a. Tahapan \\ pertama: knowledge}

Segala hal dimulai pada satu titik dengan kondisi tertentu. Pada titik ini, aka nada kemungkinan jika masyarakat memiliki suatu permasalahan dan membutuhkan solusi untuk memecahkannya alih-alih teknologi yang berkembang duluan sehingga membuat masyarakat merasa membutuhkannya.

Dalam hal ini, Whisper ada karena kebutuhan mereka yang rentan terhadap cyberbully namun memerlukan media untuk tetap bersosialisasi. Lalu mereka masuk pada tahap pertama: pengetahuan. Mereka menemukan sebuah aplikasi anonymous chat, entah karena rekomendasi sistem seperti google play atau rekomendasi dari teman yang memiliki kebutuhan yang sama.

\section{b. Tahap kedua: persuasion}

Tahap ini berarti bujukan. Telah banyak artikel-artikel yang memuat aplikasi anonymous chat, terutama artikel-artikel barat. Salah satu artikel berasal dari website Cyberbullying Research Center yang bertajuk Anonymous Postings on Confession Pages, Secret, and Whisper dan dipublikasi pada 11 April 2014. Isinya adalah betapa banyak anakanak bermasalah yang menemukan solusi baagi kehidupan social cyber mereka pada aplikasi anonymous chat seperti Whisper dan Secret.

Cyberbullying Research Center membenarkan jika aplikasi ini membuat mereka merasa nyaman dan aman untuk menyuarakan pendapat. Sebab, seperti yang sudah dijelaskan, melalui aplikasi ini kebanyakan remaja mendapat kebebasan berekspresi tanpa takut dihakimi.

Namun sudah pasti ada juga yang memberitakan sisi-sisi gelap anonymous chat. Biasanya masalah itu berputar pada perlindungan hukum dan batasbatas seseorang bisa menggunakan kebebasan berpendapat yang diperoleh.

Tentunya, artikel-artikel dan review bernada positif seperti itu akan sedikit banyak memengaruhi minat pengguna.

Khusus untuk aplikasi Whisper, quote-quote di dalamnya juga dapat dijadikan bahan untuk membujuk seseorang. Orangorang dengan pengalaman bully cenderung melankolis. Itu lah mengapa quote-quote yang bisa 'nyambung' dengan pengalaman hidup seseorang cenderung menarik perhatian.

\section{c. Tahap ketiga: decision}

ISSN 2338 - 0861 (cetak); e-ISSN 2621 - 8712 (online)

website : http://spektrum.stikosa-aws.ac.id 
Kemudian, para pengguna aplikasi ini masuk ke tahap mengambil keputusan. Ini bisa berarti menerima atau menolak aplikasi. Semua tergantung dari pandangan mereka setelah mendapat berbagai bujukan dari segala pihak dan review tentang teknologi aplikasi yang ada.

\section{d. Tahapan keempat: implementation}

Pada tahap ini, mereka menggunakan inovasi sambil mempelajari lebih jauh tentang inovasi tersebut. Analisis ini dilakukan dengan menggunakan segala fitur yang ada. Mulai dari privat message sampai berbagi quote di aplikasi Whisper. Bahkan, dalam sehari seseorang dapat melakukan privat message dengan lebih dari tiga orang asing baru.

\section{e. Tahapan kelima: confirmation}

Di tahap terakhir ini, pengguna kemudian akan mencari pembenaran atas keputusan mereka. Apakah aplikasi anonymous chat tersebut diadopsi atau tidak, secara otomatis mereka akan mempertimbangkan akibat dari keputusan yang mereka buat.

Menurut survey penulis, 10 orang berkebangsaan asing dan 10 orang berkebangsaan Indonesia dengan rentan umur $15-25$ tahun yang memakai salah satu aplikasi anonymous chat yakni Whisper, 14 orang di antaranya mengaku melalui pesan pribadi bahwa mereka sudah memakai aplikasi ini selama lebih dari tiga bulan, beberapa bahkan sudah menggunakannya selama satu atau dua tahun.

Mereka berpendapat jika aplikasi ini sangat membantu untuk mengeluarkan uneg-uneg tanpa khawatir akan diintimidasi. Semuanya mengaku jika mereka bukan lah orang yang senang mengekspos identitas personal dan cenderung bersikap introver.

Hal ini jelas berbeda dari enam orang lainnya yang mengatakan bahwa mereka tidak terlalu menikmati aplikasi ini dan berencana berhenti menggunakannya. Semuanya mengaku baru memakai Whisper selama satu atau dua bulan.

Hal itu terjadi karena dibanding aplikasi media sosial lain, anonymous chat Whisper cenderung membosankan. Padahal satu-satunya tujuan mereka menggunakan aplikasi itu adalah untuk bersenang-senang. Rupanya, mereka memang tidak memiliki latar belakang yang bergesekan langsung dengan bully atau cyberbully. Mereka merupakan orang yang aktif di media sosial Facebook, Twitter dan Instagram yang berani berekspresi dan cenderung ekstrovert.

Bagi enam orang yang berencana berhenti menggunakan aplikasi, tahapan itu akan terputus pada tahap ini. Namun itu tidak mutlak, karena bisa saja mereka baru akan menerima aplikasi itu jika suatu saat nanti keadaan menuntut hal tersebut -misalnya, mereka mengalami cyberbully di masa depan. Itu dapat dikatakan sebagai pengguna yang terlambat menerima. 
Namun, bagi ke-14 orang yang langsung menerima, tahapan selanjutnya dapat berarti kembali ke tahap bujukan di mana mereka akan berganti peran sebagai pembujuk.

Mereka akan mulai menceritakannya pada temanteman se-'nasib' mereka dan memberikan review positif tentang itu. Dengan terus menggunakan aplikasi itu, serta memberi rating di app store atau google play, secara tidak langsung akan mempermudah marketing aplikasi tersebut.

2. Pengaplikasiannya

Sektor Program Peminatan Stikosa - AWS

\section{a. Public Relations}

Sebagai penjaga nama baik perusahaaan maupun sebuah institusi, seorang Public Relations harus lah dapat menyelesaikan konflik internal dan eksternal. Ini berarti, PR harus dapat mengetahui kelompokkelompok yang menjadikan organisasi yang diwakilkannya sebagai objek pembicaraan.

Aplikasi-aplikasi anonymous chat, meski bermanfaat untuk kaum-kaum yang senang bungkam, tetap memiliki sisi gelapnya sendiri. Seseorang bisa saja menyebar kebencian dan memengaruhi orangorang yang diajaknya bicara, lalu menghilang tanpa jejak dan tidak bisa dilacak. Lagipula, ia akan berfikir jika itu sah-sah saja karena anonymous chat berarti kebebasan berpendapat dan lindungan bagi penggunanya dari penghakiman.

Jika ini terjadi atas nama institusi, lembaga, organisasi atau pun perusahaan, maka seorang PR wajib menindaklanjutinya.

Namun, karena seseorang tak dapat mempublikasikan identitas personal, sebaiknya PR menyamar sebagai pengguna. Di sini ia bisa menjadi pihak netral di mana ia akan memberi pengertian dan penjelasan sebagai penyeimbang isu. Selain itu, pembicaraan-pembicaraan di anonymous chat dapat dijadikan referensi perusahaan guna meningkatkan mutu kualitas.

\section{b. Jurnalistik}

Jika PR mencari nama baik, seorang Jurnalis sudah dikenal dalam keahliannya mencari nama buruk. Tentunya, anonymous chat ini bisa dijadikan sumber referensi isu-isu yang dapat dikembangkan dengan peliputan.

Bahkan, aplikasi itu sendiri dapat dijadikan sumber berita. Jurnalis dapat menggali sumber perlindungan hukum macam apa yang dimiliki aplikasi anonymous chat bagi parapenggunanya.

\section{c. Broadcasting}

Sesungguhnya, seorang bradcaster hampir sama dengan seorang jurnalis. Mereka mencari sumber isu yang dapat diberitakan. Hanya

ISSN 2338 - 0861 (cetak); e-ISSN 2621 - 8712 (online)

website : http://spektrum.stikosa-aws.ac.id 
saja, broadcaster lebih menyukai visual.

Untuk itu, seorang broadcaster harus bisa mengambil kepercayaan seseorang di anonymous chat yang berpotensi menjadi narasumber yang baik. Menurut pengalaman penulis, orang-orang yang tergabung dalam anonymous chat memang cenderung bersikap tertutup akan identitas perosnalnya. Namun, sekali saja pembicaraan menjadi intens dan membuat mereka nyaman, mereka sendiri lah yang akan menyarankan untuk mengubah interaksi itu menjadi lebih permanen.

Interaksi bisa saja berlanjut pada pemberitahuan nama asli, informasi kontak dan ajakn untuk berteman. Itu karena interaksi di anonymous chat sangat rentan dan bisa hilang sewaktu-waktu demi terjaganya privasi setiap pengguna. Namun, dengan pembicaraan yang baik, semua orang tentu tak akan mau kehilangan teman bicara dan diskusi yang menyenangkan.

Dari situ, seorang broadcaster bisa mendapat bentuk visual yang ia inginkan.

\section{Dampak dan Konsekuensi}

Anonymous chat bisa berdampak pada trauma berkepanjangan bagi para korban cyberbully yang tak akan kunjung sembuh. Terkadang, untuk bisa menghilangkan ketakutan, seseorang harus menghadapi ketakutan itu secara langsung.

Lagipula, seperti yang telah dijelaskan sebelumnya jika belum ada batasan yang jelas dalam menggunakan kebebasan berekspresi dan berpendapat dalam aplikasi ini. Ini bisa berarti seseorang dapat membicarakan tentang percobaan makar dan berkelit bahwa itu adalah haknya untuk berbicara. Tak adanya kolom komentar atau pun diskusi publik tentang apa yang mungkin didiskusikan, dan tidak tersedinya fitur pengeksposan identitas personal, membuat penggunapengguna tak bertanggungjawab bebas dari kritik sosial serta penghakiman massa.

Namun, tentu saja hal-hal seperti itu telah dipredikdi oleh para pendiri aplikasi-aplikasi anonymous chat. Memang, di Indonesia sendiri aplikasi semacam ini belum terlalu popular, namun bagi perusahaan aplikasiaplikasi anonymous chat besar seperti Secret, Whisper atau Yik-Yak, data pengguna dikirimkan pada FBI dan M15 sehingga mereka dapat mengawasi aktivitas dalam anonymous chat.

\section{KESIMPULAN}

Pengguna anonymous chat kebanyakan adalah orang yang rentan terhadap cyberbully. Mereka juga merupakan orang-orang berkepribadian introvert yang tak senang membagi identitas personal di 
depan publik melalui media sosial seperti Instagram atau Facebook. Anonymous chat membuat pengguna merasa aman dari penghakiman massa dan memiliki kemerdekaan menyuarakan isi kepala. Anonymous chat tentu masih memiliki sisi gelap seperti tidak jelasnya batas kebebasan berpendapat dan aspek hukum yang abu-abu di Indonesia. Anonymous chat yang sudah memiliki nama-nama besar merupakan perkembangan teknologi yang penggunanya sudah mencapai ratusan juta orang. Ini tentu berpotensi menjadi alasan pergeseran sistem sosial masyarakat di masa depan.

\section{DAFTAR PUSTAKA}

\section{Buku}

Baumeister, Roy F. The Self in Social Psychology. Psychology Press, 1999.

Horney, Karen. Our Inner Conflicts: A Constructive Theory of Neurosis. Norton, 1992.

\section{Artikel dari website tanpa nama penulis}

https://en.wikipedia.org/wiki/Discon nect (film)

https://en.wikipedia.org/wiki/Whisp er (app) http://cyberbullying.org/anonymouspostings-confession-secret-

whisper

\section{Jurnal cetak}

Choria Y., (2014). Cyberbullying di Kalangan Remaja., Studi tentang Korban Cyberbullying di Kalangan Remaja di Surabaya.

Kowalski, R.M., Limber, S.P., \& Agatston, P.W. (2008). Cyberbullying: Bullying in the digitalage. Oxford: Blackwell Publishing. 